\title{
Pengaruh Komposisi Susu, Tepung Telur dan Tepung Beras terhadap Kualitas dan Organoleptik Biskuit
}

\section{Effect of Combination of Milk, Egg Powder and Rice Flour on Biscuits Quality and Organoleptics}

\author{
E. Vebriyanti dan R. Kurniawan \\ Fakultas Peternakan Universitas Andalas \\ Kampus Unand Limau manis, Padang 25163 \\ Email:elyvebriyanti@yahoo.com \\ (Diterima 18 November ; Disetujui 15 Januari)
}

\begin{abstract}
The research objectives are determination of concentration of milk, rice flour and egg powder on protein, fat, crude fibre, and organoleptic evaluation on biscuit. The experiment was designed by using Randomized Block Design with 4 treatments: A (egg powder 20\%, skim milk 33\%, rice flour 7\%), B (egg powder $25 \%$, skim milk $25 \%$, rice flour $10 \%$ ), C (egg powder $30 \%$, skim milk $17 \%$, rice flour $13 \%$ ), D (egg powder $35 \%$, skim milk $9 \%$, rice flour $16 \%$ ), and each treatment was repeated 5 times. Parameters observed were protein, fat, crude fibre, and organoleptic of biscuit. Result shown, the concentration of milk, rice flour and egg powder affected protein, fat, crude fibre, and organoleptic of biscuit highly significant $(P<0.01)$. In conclusion, the best concentration of milk, rice flour, and egg powder for biscuit were $9 \%, 16 \%$, and $35 \%$ respectively.
\end{abstract}

Keywords: Biscuit, protein, fat content, organoleptic

\section{PENDAHULUAN}

Biskuit merupakan salah satu kue kering yang sangat digemari oleh kalangan anak-anak dan orang dewasa. Inti pembuatan kue kering adalah pencampuran tepung dan air yang dijadikan adonan kemudian ditambahkan dengan bahan yang mengandung lemak agar biskuit menjadi renyah (Gracia et al., 2009).

Susu merupakan bahan makanan yang sangat penting untuk kebutuhan manusia karena mengandung zat makanan yang sangat diperlukan oleh tubuh seperti protein, karbohidrat, lemak, vitamin dan mineral. Karena nilai gizi dan kandungan yang khas inilah yang menjadikan susu sebagai bahan makanan yang disukai untuk dikonsumsi secara langsung. Tetapi susu mempunyai sifat yang mudah rusak karena susu mengandung berbagai komponen bahan pangan yang merupakan bagian sangat baik untuk pertumbuhan mikroorganisme seperti bakteri, kapang dan khamir sehingga dapat menurunkan mutu susu sehingga tidak tahan lama. Antisipasi susu ini tidak terbuang maka perlu dilakukan usaha penanganan dan pengolahan sehingga dapat menekan pencemaran susu oleh bakteri yang sekaligus meningkatkan pemanfaatan susu tersebut dengan jalan diolah menjadi campuran dalam pembuatan biskuit demikian pula tepung telur (Widodo et al., 2003).

Telur merupakan bahan makanan yang sempurna karena telur mengandung zat-zat gizi yang kaya protein $(45 \%)$, lemak $(40 \%)$ dan zat-zat lainnya yang dibutuhkan oleh tubuh menurut Hadiwiyoto (1983). Ditambahkan Syamsir et al. (1994). Kualitas telur ditentukan oleh makanan dan level protein ransum. Selain komposisi yang ideal tersebut telur juga mengalami sifat yang mudah rusak karena rantai pemasaran yang dilalui oleh telur cukup panjang dari peternak, pedagang dan akhirnya sampai ketangan konsumen.

Salah satu cara mempertahankan kualitas telur tersebut adalah dengan mengolah telur menjadi tepung telur utuh dan dapat dimanfaatkan sebagai campuran dalam pembuatan biskuit. Pemakaian bahan-bahan seperti susu, tepung telur dan tepung beras serta bahan tambahan lainnya diharapkan kandungan gizi seperti protein, lemak dan serat kasar dalam pembuatan biskuit menjadi lebih baik. Penambahan tepung beras sebagai bahan tambahan yang mengandung pati dimaksudkan sebagai pengganti tepung terigu. 
Tujuan penelitian ini adalah untuk menentukan level pemakaian kombinasi susu, tepung telur dan tepung beras terhadap kualitas dan oganoleptik serta meningkatkan nilai tambah dan nilai gizi biskuit. Berdasarkan latar belakang tersebut maka dilakukan penelitian "Kombinasi berbagai komposisi Susu, Tepung Telur, Tepung Beras terhadap Kualitas dan Nilai Organoleptik Biskuit".

\section{MATERI DAN METODE}

Materi yang digunakan dalam penelitian ini adalah $1.677,5 \mathrm{~g}$ tepung telur (TT), $1.281 \mathrm{ml} \mathrm{Susu}$ segar Sapi FH (SS), 701,5 g tepung beras (TB), $1.220 \mathrm{~g}$ gula pasir, $1.159 \mathrm{~g}$ margarin dan $61 \mathrm{~g}$ baking powder.

Metode yang digunakan dalam penelitian ini adalah metode eksperimen menggunakan Rancangan Acak Kelompok (RAK) yang terdiri dari 4 perlakuan dan 5 kelompok sebagai ulangan. Perlakuan A, TT $20 \%$, SS $33 \%$, TB 7\%, perlakuan B, TT $25 \%$, SS $25 \%$, TB $10 \%$, perlakuan C, TT $30 \%$, SS $17 \%$, TB $13 \%$ dan perlakuan D, TT $35 \%$, SS $9 \%$, TB $16 \%$. Peubah yang diukur adalah kadar protein, lemak, serat kasar, dan penilaian organoleptik.

Data yang diperoleh diuji secara statistik menggunakan analisis keragaman Rancangan Acak Lengkap dan perbedaan antar perlakuan dilanjutkan dengan uji lanjut Duncan's Multiple Range Test (DMRT).

Untuk organoleptik digunakan uji skala (Scalling Test) yaitu dengan menggunakan garis sebagai parameter penentuan kesan dari suatu rangsangan yang menggunakan gambar skala berbentuk garis vektor yaitu garis lurus yang mempunyai titik pangkal dan arah, titik pangkal menunjukkan nilai batas awal sedangkan ujung garis menyatakan nilai tertinggi. Selanjutnya dilakukan analisis Uji Least Significant Difference (LSD).

\section{HASIL DAN PEMBAHASAN}

\section{Kadar protein}

Pada Tabel 1 dapat dilihat bahwa semakin tinggi level pemberian TT dan TB menyebabkan terjadinya peningkatan kadar protein biskuit yang dihasilkan pada setiap perlakuan. Kadar protein biskuit tertinggi pada pada perlakuan D yaitu $25,89 \%$ dan yang terendah pada perlakuan A yaitu $18,88 \%$. Hal ini disebabkan karena pada perlakuan D persentase pemberian TT $35 \%$, TB 16\% lebih banyak sedangkan SS sedikit hanya $9 \%$ dibandingkan dengan perlakuan lainnya.

Berdasarkan hasil analisis keragaman menunjukkan bahwa kombinasi SS, TT dan TB yang berbeda pada pembuatan biskuit memberikan pengaruh sangat nyata $(\mathrm{P}<0,01)$ terhadap kadar protein. Hasil analisis uji lanjut DMRT menunjukkan bahwa kadar protein biskuit perlakuan $\mathrm{D}$ berbeda sangat nyata $(\mathrm{P}<0,01)$ terhadap perlakuan $\mathrm{A}, \mathrm{B}$ dan $\mathrm{C}$ sedangkan perlakuan $\mathrm{C}$ berbeda sangat nyata $(\mathrm{P}<0,01)$ terhadap perlakuan $\mathrm{A}$ dan $\mathrm{B}$ demikian pula perlakuan $B$ berbeda sangat nyata $(P<0,01)$ dengan perlakuan A.

Campuran SS, TT dan TB yang berbeda akan memberikan pengaruh berbeda sangat nyata terhadap kadar protein biskuit pada masing-masing perlakuan dimana semakin banyak persentase pemberian tepung telur dan tepung beras maka semakin tinggi kadar protein biskuit yang dihasilkan.

Menurut Hadiwiyoto (1983) menyatakan komposisi utama susu adalah air, lemak, laktosa, mineral dan protein dengan komposisi protein berkisar 3-5\%. Ditambahkan Munadjim (1983) menyatakan tepung beras merupakan bahan mentah yang baik sebagai tambahan untuk membuat berbagai macam makanan, tepung beras mengandung protein $6.80 \%$. Ditambahkan oleh

Tabel 1. Rataan kadar protein, lemak, serat kasar biskuit

\begin{tabular}{cccc}
\hline Perlakuan & Kadar Protein & Lemak & Serat Kasar \\
\hline A & $18,88^{\mathrm{a}}$ & $30,63^{\mathrm{a}}$ & $0,36^{\mathrm{a}}$ \\
B & $22,11^{\mathrm{b}}$ & $32,90^{\mathrm{b}}$ & $0,45^{\mathrm{b}}$ \\
C & $24,04^{\mathrm{c}}$ & $33,84^{\mathrm{c}}$ & $0,84^{\mathrm{c}}$ \\
D & $25,89^{\mathrm{d}}$ & $36,86^{\mathrm{d}}$ & $1,02^{\mathrm{d}}$ \\
\hline Rata -rata & 22,73 & 33,55 & 0,68 \\
\hline
\end{tabular}

Keterangan : Superskrip berbeda pada kolom yang sama menunjukkan berbeda sangat nyata $(\mathrm{P}<0,01),(\mathrm{A}=\mathrm{TT} 20 \%$, ss $3 \%$, TT $35 \%$, ss $9 \%$, TB $16 \%$ ) 
Robert (1989), komponen utama TB adalah pati sedangkan protein merupakan komponen kedua dalam beras. Meningkatnya kadar protein pada setiap perlakuan disebabkan karena meningkatnya penggunaan SS, TT dan TB untuk perlakuan selanjutnya. Hal ini didukung oleh Definiati dan Sartini (2006), produksi susu ditentukan oleh faktor lingkungan, genetik dan lingkungan Ditambahkan oleh Sudarwanto dan Sudarnika (2008), SS yang dihasilkan dipengaruhi oleh tata laksana dan penyakit ternak.

Biskuit yang dihasilkan pada penelitian ini memenuhi kadar protein minimum sesuai dengan ketetapan Departemen Perindustrian (1992) pada SNI 01-2973-92 yang menetapkan bahwa kadar protein biskuit minimal adalah $6 \%$. Kadar protein biskuit yang dihasilkan lebih tinggi dari SNI 012973-92. Hal ini disebabkan karena komposisi bahan campuran biskuit penelitian menggunakan bahan kombinasi SS, TT dan TB dengan level yang berbeda. Sedangkan berdasarkan Standar Nasional Indonesia (1994), komposisi biskuit yang dibuat terdiri dari susu, telur, tepung terigu dan bahan tambahan lainnya.

\section{Kadar lemak}

Pada Tabel 2 dapat dilihat bahwa semakin rendah level pemberian SS dan semakin tinggi level pemberian TT dan TB menyebabkan terjadinya peningkatan kadar lemak biskuit yang dihasilkan pada setiap perlakuan. Kadar lemak tertinggi terdapat pada perlakuan D yaitu $36,86 \%$ dan yang terendah pada perlakuan A yaitu 30,63\%.

Hasil analisis keragaman menunjukkan bahwa kombinasi SS, TT dan TB dengan level yang berbeda pada pembuatan biskuit penelitian berpengaruh sangat nyata $(\mathrm{P}<0,01)$ terhadap kadar lemak. Hasil uji lanjut DMRT memperlihatkan bahwa perlakuan $\mathrm{D}$ berbeda sangat nyata $(\mathrm{P}<0,01)$ terhadap perlakuan A, B dan C. Demikian juga perlakuan $C$ berbeda sangat nyata $(P<0,01)$ terhadap perlakuan $\mathrm{A}$ dan berbeda nyata terhadap perlakuan $B$ sedangkan perlakuan $B$ berbeda sangat nyata terhadap perlakuan $\mathrm{A}$.

Pemakaian kombinasi SS, TT dan TB dengan level yang berbeda memberikan pengaruh berbeda sangat nyata terhadap masing-masing perlakuan dimana semakin banyak persentase TT dan TB dan semakin rendah persentase susu yang digunakan maka semakin tinggi kadar lemak biskuit yang dihasilkan sebaliknya semakin tinggi persentase pemakaian susu dan semakin rendah pemakaian TT dan TB maka kadar lemak biskuit akan semakin rendah. Hal ini disebabkan karena TT mengandung lemak lebih tinggi dibandingkan dengan TB maupun SS. Sedangkan Menurut Munadjim (1983) bahwa TB merupakan bahan mentah yang baik untuk membuat berbagai macam makanan karena TB sedikit mengandung lemak $0,70 \%$ sedangkan susu mengandung lemak sebesar 4\% (Hadiwiyoto, 1983) ditambahkan oleh Winarno dan Koswara (2002) bahwa TT utuh terbuat dari campuran kuning dan putih telur dengan proporsi alamiah telur segar. Menurut Gracia et al. (2009), bahwa jumlah dan jenis lemak yang digunakan tergantung pada jenis biskuit yang akan dibuat.

Berdasarkan data dari pengamatan yang dilakukan kadar lemak yang terkandung dalam biskuit sudah memenuhi kadar minimum biskuit yang ditetapkan oleh Departemen Perindustrian (1992) pada SNI 01-2973-92 adalah 9,5\%.

\section{Kadar serat kasar}

Pada Tabel 3 dapat lihat bahwa semakin tinggi level pemberian TT dan TB menyebabkan terjadinya peningkatan kadar serat kasar biskuit yang dihasilkan pada setiap perlakuan. Kadar serat kasar biskuit tertinggi terdapat pada perlakuan $\mathrm{D}$ yaitu $1,02 \%$ dan yang terendah pada perlakuan A yaitu $0,36 \%$. Hal ini disebabkan karena pada perlakuan D persentase pemberian TT $35 \%$, TB 16\% lebih banyak dibandingkan dengan perlakuan lainnya. Menurut Standar Nasional Indonesia (1994) No. 01-35491994 menyakan bahwa kandungan serat kasar tepung beras sebesar $1 \%$. Berdasarkan analisis keragaman bahwa kombinasi SS, TT dan TB yang berbeda pada pembuatan biskuit memberikan pengaruh sangat nyata $(\mathrm{P}<0,01)$ terhadap serat kasar biskuit. Hasil analisis uji lanjut DMRT menunjukkan bahwa kadar serat kasar biskuit perlakuan $\mathrm{D}$ berbeda sangat nyata $(\mathrm{P}<0,01)$ terhadap perlakuan $\mathrm{A}, \mathrm{B}$ dan $C$, sedangkan perlakuan $C$ berbeda sangat nyata $(\mathrm{P}<0,01)$ terhadap perlakuan $\mathrm{A}$ dan $\mathrm{B}$ demikian pula pada perlakuan $B$ berbeda sangat nyata $(P<0,01)$ dengan perlakuan $\mathrm{A}$.

Pemakaian campuran SS, TT dan TB yang berbeda akan memberikan pengaruh berbeda sangat nyata terhadap serat kasar biskuit pada masing-masing perlakuan dimana semakin banyak persentase pemberian TT dan TB maka semakin tinggi kadar serat kasar biskuit yang dihasilkan hal ini disebabkan karena TB mengandung serat kasar yang tinggi dan TT mengandung protein yang tinggi. Menurut Standar Nasional Indonesia (1994) No. 01-3549-1994 menyakan bahwa kandungan serat kasar tepung beras sebesar $1 \%$.

Menurut Muchtadi, Palupi, dan Astawan (1992) serat makanan adalah komponen dalam 
Tabel 2. Rataan penilaian panelis terhadap rasa dan tekstur biskuit

\begin{tabular}{ccc}
\hline Perlakuan & Rasa & Tekstur \\
\hline A & $4,16^{\mathrm{a}}$ & $3,96^{\mathrm{a}}$ \\
B & $5,08^{\mathrm{a}}$ & $5,16^{\mathrm{ab}}$ \\
C & $5,44^{\mathrm{ab}}$ & $6,28^{\mathrm{bc}}$ \\
D & $5,88^{\mathrm{ab}}$ & $6,52^{\mathrm{c}}$ \\
\hline Rata-rata & 5,14 & 5,41 \\
\hline
\end{tabular}

Keterangan : Superskrip berbeda pada kolom yang sama menunjukkan berbeda sangat nyata $(P<0,01),(A=T T 20 \%$, ss $3 \%$, TT $35 \%$, ss $9 \%$, TB $16 \%$ )

tanamanan yang tidak tercerna secara ezimatis sehingga sebagai sumber zat makanan tetapi bermanfaat terhadap kesehatan yang termasuk dalam kategori serat adalah selulosa, lignin dan hemiselulosa dari dinding tanaman pektin yang merupakan komponen non struktural sel tanaman. Departemen Perindustrian (1992) pada SNI 01-2973-92 menyatakan kadar serat kasar maksimal $0,5 \%$ berarti kadar serat kasar pada perlakuan A dan B telah memenuhi syarat mutu biskuit tetapi pada perlakuan C danD belummemenuhi syarat mutu biskuit.

\section{Nilai organoleptik}

Rasa Pada Tabel 2 dapat dilihat bahwa ratarata nilai organoleptik terhadap rasa biskuit hasil penelitian nilai tertinggi diberikan panelis paling tinggi pada perlakuan D yaitu biskuit dengan campuran TT $33 \%$, SS $9 \%$ dan TB $17 \%$ sedangkan nilai rasa terendah adalah pada perlakuan A yaitu biskuit dengan campuran TT $20 \%$, SS $33 \%$ dan TB $7 \%$. Hal ini disebabkan tepung telur mengandung kadar protein $45 \%$ (Winarno dan Koswara, 2002) dan susu mengandung kadar protein 3,3\% (Hadiwiyoto, 1983) sehingga dapat memberikan rasa enak dan disukai panelis karena mengandung protein yang tinggi tergantung pada reaksi kelompok asam amino dengan dengan gula.

Hasil analisis keragaman menunjukkan bahwa kombinasi SS, TT dan TB berpengaruh nyata $(\mathrm{P}<0,05)$ terhadap cita rasa biskuit yang dihasilkan. Rasa adalah salah satu faktor yang mempengaruhi nilai penerimaan seseorang terhadap suatu makanan. Rasa biskuit dibentuk oleh rangsangan terkadang juga dipengaruhi oleh aroma dan warna. Penerimaan panelis terhadap rasa dipengaruhi oleh beberapa faktor antara lain senyawa kimia, suhu, konsentrasi dan interaksi dengan komponen rasa lainnya (Winarno, 1997).
Dari hasil uji LSD (Least Significant Difference) menunjukkan biskuit perlakuan D (D/725) berbeda nyata terhadap rasa biskuit pada perlakuan A (A/528), namun tidak berbeda nyata terhadap kedua perlakuan biskuit yang lainnya yaitu perlakuan $\mathrm{B}(\mathrm{B} / 710)$ dan perlakuan $\mathrm{C}$ $(\mathrm{C} / 421)$. Perlakuan $\mathrm{C}$ berbeda nyata $(\mathrm{P}<0,05)$ dengan perlakuan $\mathrm{A}$ tetapi tidak berbeda nyata dengan perlakuan B. Perlakuan B tidak berbeda nyata dengan perlakuan $A$ pada tingkat rasa enak biskuit. Biskuit pada perlakuan D paling tinggi tingkat rasa enaknya dengan rata-rata 5,88 sedangkan yang paling rendah tingkat rasa enaknya adalah biskuit pada perlakuan A dengan rata-rata 4,16. Jadi panelis memberikan tingkat rasa enak biskuit dari yang paling enak sampai kurang rasa enaknya adalah biskuit pada perlakuan $\mathrm{D}, \mathrm{C}, \mathrm{B}$ dan biskuit pada perlakuan A. Pada waktu pembuatan adonan pada perlakuan D penggunaan TT 33\%, SS $9 \%$ dan TB $16 \%$ dapat memberikan rasa enak sedangkan pada perlakuan A dengan TT $20 \%$, SS $33 \%$ dan TB $7 \%$ memberikan rasa kurang enak dimana rasa yang ditimbulkan dipengaruhi oleh komposisi nutrisi yang terkandung pada bahan yang digunakan dalam pembuatan biskuit.

Menurut Soekarto (1985) bahwa rasa merupakan campuran dari tanggapan, rasa dan bau yang diramu oleh kesan lain seperti penglihatan, sentuhan dan aroma atau flavour dari produk itu sendiri. Ditambahkan Buckle, Edward, Fleet dan Wootton (1987), bahwa rasa yang timbul dari produk biskuit dipengaruhi oleh komposisi bahan yang digunakan dalam pembuatan produk olahan selanjutnya ditambahkan bahwa cita rasa dari bahan pangan yang dimasak dan diolah sangat tergantung pada reaksi kelompok asam amino dengan dengan gula pereduksi yang menghasilkan warna coklat dan cooked flavor dari berbagai komponen cita rasa. Faktor lain yang juga sangat mempengaruhi adalah selera yang sifatnya sangat subjektif. 
Tekstur Hasil analisis keragaman memperlihatkan bahwa penambahan tepung telur, susu dan tepung beras berpengaruh sangat nyata $(\mathrm{P}<0,01)$ terhadap tekstur biskuit yang dihasilkan. Dari hasil uji LSD (Least Significant Difference) menunjukkan biskuit perlakuan D (D/725) berbeda nyata terhadap biskuit perlakuan A $(\mathrm{A} / 528)$ dan biskuit perlakuan $\mathrm{B}(\mathrm{B} / 710)$, namun berbeda tidak nyata terhadap biskuit perlakuan $\mathrm{C}$ (C/421). Biskuit perlakuan $\mathrm{C}$ berbeda nyata terhadap biskuit perlakuan A dan berbeda tidak nyata terhadap biskuit perlakuan B, sedangkan biskuit perlakuan $\mathrm{B}$ tidak berbeda nyata dengan biskuit perlakuan A pada tingkat kerenyahan biskuit. Biskuit pada perlakuan A paling rendah tingkat kerenyahannya dengan rata-rata 3,96 sedangkan biskuit pada perlakuan $\mathrm{D}$ paling tinggi tingkat kerenyahannya dengan rata-rata 6,52.

Jadi urutan tingkat kerenyahan biskuit dari yang paling renyah sampai kurang renyah adalah biskuit perlakuan D, C, B dan perlakuan A. Hal ini disebabkan Pada waktu pengolahan terjadi peningkatan suhu sehingga kadar air adonan biskuit menurun dan akan cepat mengalami kekeringan yang mengakibatkan biskuit hasil penelitian menjadi renyah. Selain itu juga disebabkan oleh adanya kadar-kadar lemak yang menyebabkan rendahnya stabilitas. Sesuai pendapat Associates (1981) menyatakan bahwa tekstur dapat dipengaruhi oleh lemak sehingga bahan pangan tersebut menjadi gurih dan rasa menjadi lebih enak. Ditambahkan Soeparno (1994) bahwa pada prinsipnya pengaruh pemanasan dapat meningkatkan dan menurunkan keempukkan dari suatu bahan makanan dan kedua pengaruh itu tergantung pada waktu dan temperatur pemasakan. Hal ini juga didukung oleh pernyatan Winarno (1997) bahwa tekstur suatu bahan akan mempengaruhi cita rasa dari makanan tersebut.

\section{KESIMPULAN}

Berdasarkan hasil penelitian dapat disimpulkan bahwa kombinasi susu, tepung telur dan tepung beras yang paling baik untuk menghasilkan protein dan lemak yang tinggi serta nilai organoleptik terhadap rasa dan tekstur yaitu tepung telur $35 \%$, susu $9 \%$ dan tepug beras $16 \%$.

\section{DAFTAR PUSTAKA}

Associates, U.S.W. 1981. Pedoman Pembuatan Roti dan Kue. Djambatan, Jakarta.
Buckle, K.A., R.A. Edward., G.H. Fleet, dan M. Wootton. 1987. Ilmu Pangan. Terjemahan Hari Purnomo dan Adiono. Indonesia University Press, Jakarta.

Departemen Perindustrian. 1992. Standar Mutu Biskuit Menurut Standar Nasional Indonesia. Departemen. Perindustrian.

Definiati, N. dan Sartini. 2006. Pendugaan daya produksi susu dan beberapa Nilai parameter genetik pada sapi perah Fries Holland, Jurnal Peternakan Indonesia 11 (1)

Gracia C.L.C, Sugiyono, dan B. Haryanto. 2009.Kajian formulasi biskuit jagung dalam rangka subsitusi tepung terigu. Jurnal Teknologi dan Industri Pangan XX (1)

Hadiwiyoto, S. 1983. Hasil-hasil Olahan Susu, Ikan, Daging, dan Telur. Lyberty, Yogyakarta.

Muaris, H. 2007. Biskuit Sehat. PT. Gramedia Pustaka, Jakarta.

Muchtadi. D, Palupi, dan Astawan, M. 1992. Metode Kimia Biokimia dan Biologi dalam Evaluasi Gizi Pangan dan Olahan. Pusat Antar Universitas Pangan dan Gizi. Institut Pertanian Bogor, Bogor.

Munadjim. 1983. Teknologi Pengolahan Pisang. PT. Gramedia Jakarta, Jakarta.

Robert, H. 1989. Evaluasi Gizi pada Pengolahan Bahan Pangan. Institut Pertanian Bogor, Bogor.

Soekarto, S.T. 1985. Penilaian Organoleptik. Bhratara Karya Aksara, Jakarta.

Soeparno. 1994. Ilmu dan Teknologi Daging. Gadjah Mada University Press, Yogyakarta.

Standar Nasional Indonesia. 1994. Mutu dan Cara Uji Tepung Beras. Badan Standar Nasional Indonesia, Jakarta.

Sudarwanto, M. dan E. Sudarnika. 2008. Hubungan antara $\mathrm{pH}$ susu dengan jumlah sel somatik sebagai parameter mastitis subklinis. Media Peternakan, Jurnal Ilmu pengetahuan dan Teknologi Peternakan, vol. 31 (2).

Suprapti, M.L. 2002. Pengawetan Telur. Konisius, Yogyakarta.

Syamsir.E, T.S Soekarto, dan S.S.Mansjoer. 1994. Studi komparatif sifat mutu dan fungsional telur puyuh dan telur ayam ras. Jurnal Teknologi dan Industri Pangan V (3) :34-38. 
Widodo, Soeparno, dan E. Wahyuni. 2003. Bionkapsulasi Probiotik (Lactobacillus casei) dengan pollard dan tepung terigu serta pengaruhnya terhadap viabilitas dan laju pengasaman. Jurnal Teknologi dan Industri Pangan XIV (2) : 98-106.
Winarno, F.G. 1997. Kimia Pangan dan Gizi. PT. Gramedia Pustaka Utama, Jakarta.

Winarno, F.G. dan Koswara, S. 2002. Telur: Komposisi, Penanganan dan Pengolahannya. M-Brio Press, Bogor. 